\title{
Research note: A rock mulch layer supported little vegetation in an arid reclamation setting
}

\author{
Jeffrey S. Fehmi
}

To cite this article: Jeffrey S. Fehmi (2018) Research note: A rock mulch layer supported little vegetation in an arid reclamation setting, Arid Land Research and Management, 32:2, 253-256, DOI: 10.1080/15324982.2017.1391356

To link to this article: https://doi.org/10.1080/15324982.2017.1391356

\section{曲 Published online: 07 Nov 2017.}

Submit your article to this journal $\pi$

\section{Article views: 17}

Q View related articles $\sqsubset$

View Crossmark data ¿ 


\title{
Research note: A rock mulch layer supported little vegetation in an arid reclamation setting
}

\author{
Jeffrey S. Fehmi \\ School of Natural Resources and the Environment, University of Arizona, Tucson, AZ, USA
}

\begin{abstract}
Adding a surface rock layer (also called rock armor or rock mulch) to constructed slopes improves erosion resistance but has had mixed effects on revegetation. This study investigated the effects of rock layer depth (no rocks, 10-, 15-, and 20-cm rock layers) and rock size (5-20 cm diameter rocks) on vegetation cover. Seeding was applied four times in the first 2 years. After 3 years, plots with a rock layer averaged $7 \%$ vegetative cover compared to $85 \%$ on plots without a rock layer. There was a nonsignificant trend toward less vegetation with a deeper rock layer.
\end{abstract}

\section{ARTICLE HISTORY}

Received 24 January 2017 Accepted 9 October 2017

\section{KEYWORDS}

Constructed slopes; rock armor; rock depth; Sonoran desert

For many constructed slopes and landfill closure applications, such as mine tailings or waste dumps, the final land forms have been expected to last from 50 to 200 years, 1000 years, or the most ambitious "in perpetuity" (Blight and Amponsah-da Costa 2004; DeJong, Tibbett, and Fourie 2015). The use of a surface rock layer (also called rock armor or rock mulch) has been a common treatment/method to minimize erosion and loss of slope stability. The surface rocks act to reduce soil erosion directly by reducing soil detachment by raindrop impacts or other disturbance as well as indirectly by reducing both the quantity and energy of surface runoff (Wang et al. 2012). For example, Thornton, Abt, and Johnson (1998) recommended rocks larger than $9 \mathrm{~cm}$ average diameter in a layer greater than $27 \mathrm{~cm}$ thick to prevent gully formation during heavy storms. A rock layer can also prevent wind (aeolian) erosion (Zhang et al. 2015) and capture aeolian sediment (Li and Lui 2003).

While slope stability remains the most important criteria for reclaiming a site, revegetating slopes has been commonly required so that reclaimed sites are suitable for reuse, equivalent to undisturbed sites, or more aesthetically pleasing (Sheoran, Sheoran, and Poonia 2010). In addition, vegetation can increase slope stability (DeJong, Tibbett, and Fourie 2015). In a review comparing surface application of organic mulch, rock fragments, and vegetation, Smets, Poesen, and Bochet (2008) found vegetation to be the most effective in reducing erosion but, in arid and semiarid lands, vegetation can be absent in the months or years before it establishes and, once established, vegetation can be lost to fire or drought.

Combinations of rock layers and vegetation, which may minimize erosion potential, have been used (Gyasi-Agyei 2004) and rocks can conserve soil moisture beneath them (Katra, Lavee, and Sarah 2008; Kaseke et al. 2012). In more mesic systems where vegetation 
is limited by light or available space, addition of rock may reduce the amount of potential vegetation (Sheoran, Sheoran, and Poonia 2010). This is less clear in arid and semiarid areas because the availability of water limits vegetation, rather than available space, and rock mulch may have a positive, neutral, or negative effect on the amount of vegetation.

This study was established to evaluate the ability of rock layers to support vegetation in a hot semi-arid reclamation setting. The hypotheses were that (1) a minimum realistic rock layer would have a neutral to positive effect on plant establishment and (2) as the depth of rock increased, the amount of vegetation would decrease.

Four depths of rock were tested on a flat clay loam surface at the University of Arizona agricultural center (Tucson, Arizona, USA; $32^{\circ} 16^{\prime} 51.77^{\prime \prime} \mathrm{N}, 110^{\circ} 56^{\prime} 13.14^{\prime \prime} \mathrm{W} ; 716 \mathrm{~m}$ asl; within the Sonoran Desert). The soil was excavated to $46 \mathrm{~cm}$ (18 in) and then put back to simulate a reclamation scenario. This process also removed all vegetation within $3 \mathrm{~m}$ of the plots. The rock was sourced equally from two locations: first, granitic and metamorphic rock $\left(31^{\circ} 50^{\prime} 34.30^{\prime \prime} \mathrm{N}, 110^{\circ} 45^{\prime} 05.96^{\prime \prime} \mathrm{W}, 1615 \mathrm{~m}\right.$ asl) and, second, from fan alluvium from mixed sources $\left(31^{\circ} 49^{\prime} 20.48^{\prime \prime} \mathrm{N}, 110^{\circ} 44^{\prime} 03.62^{\prime \prime} \mathrm{W}, 1501 \mathrm{~m}\right.$ asl). Rocks, 5-20 cm in diameter, were placed in 10,15 , and $20 \mathrm{~cm}$ thick layers in $91 \times 91 \mathrm{~cm}$ plots. Control plots had no rocks. These four treatments were replicated four times in a randomized design. Plots were separated by $2 \mathrm{~m}$.

The experiment was set up in June 2013 and seeded four times: 2 July 2013, 20 August 2013, 30 June 2014, and 22 August 2014. The commercially acquired 10-species seed mix included: 14\% Digitaria californica (Benth.) Henr., a warm season perennial grass (WSPG); $14 \%$ Bouteloua gracilis (Willd. ex Kunth) Lag. ex Griffiths, WSPG; 14\% Hilaria belangeri (Steud.) Nash, WSPG; 14\% Leptochloa dubia (Kunth) Nees, WSPG; 14\% Eragrostis intermedia Hitchc., WSPG; 14\% Bouteloua curtipendula (Michx.) Torr., WSPG; 3\% Elymus elymoides (Raf.) Swezey, a cool-season perennial grass; 8\% Eschscholzia californica Cham. ssp. mexicana (Greene) C. Clark, an annual forb; $4 \%$ Baileya multiradiata Harv. \& A. Gray ex A. Gray, a perennial forb; and 2\% Calliandra eriophylla Benth., an N-fixing shrub. The seed mix was hand applied with a total of 455 seeds per plot (a rate of 550 seeds per $\mathrm{m}^{2}$ ) which matches the recommended seeding rate for the region.

Cover of all vegetation rooted within the plots was assessed on 9 March 2016 which included vegetation from the 2015 summer as well as the 2015-2016 winter-growing season. Total plant cover was visually assessed in the center $50 \times 50 \mathrm{~cm}$ of the plots to avoid the prominent edge effects. Cover was chosen as a nondestructive method which characterizes plant abundance as well as its common use for judging revegetation success. The study site received 189, 278, and $320 \mathrm{~mm}$ precipitation in 2013, 2014, and 2015, respectively, and 1987-2015 average annual precipitation of $273 \mathrm{~mm}$. Fencing $(25 \mathrm{~mm}$ mesh) protected the plots from large herbivores and rabbits. Small mammals were controlled with poison baits in the late winters of each year through 2016.

The data was analyzed as an ANOVA using R 3.2.2 (R Foundation for Statistical Computing, 2015, Vienna, Austria). Tukey's multiple comparisons of means was used to determine significance of differences between means.

The plots without rock cover had significantly more vegetation cover $(P<0.001$; Figure 1) than the plots with rocks. The seeding had poor success with seeded species comprising less than $5 \%$ of the vegetation in all plots. The remaining vegetation was locally recruited volunteer species not among the species in the seed mix. However, the differences 


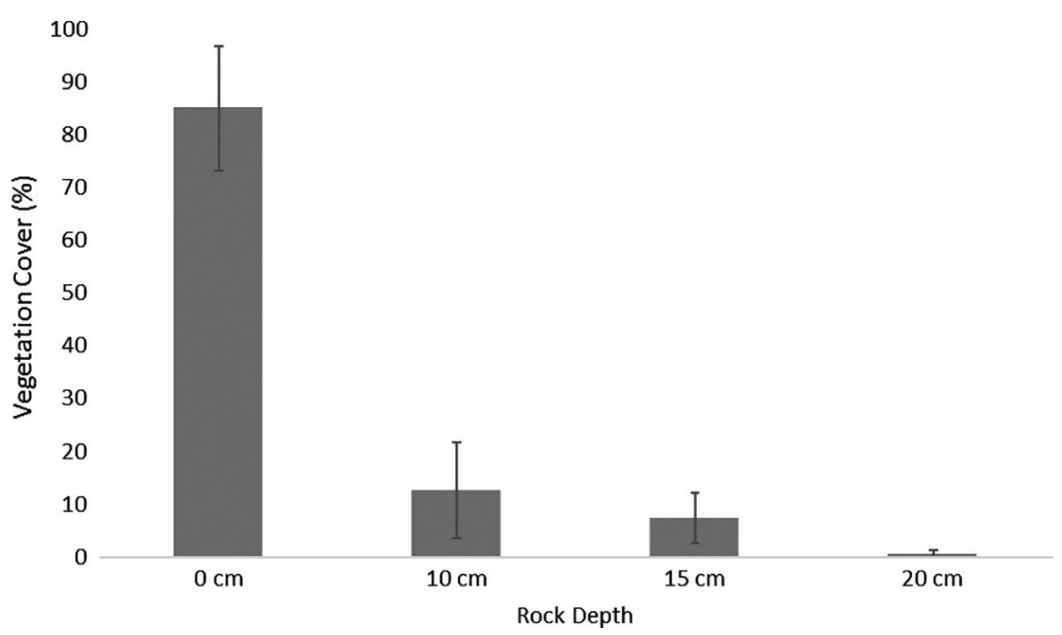

Figure 1. Estimated cumulative vegetation cover after 3 years for layers of $5-20 \mathrm{~cm}$ diameter rocks. Error bars represent standard error of the mean.

among the rock treatments were unlikely to be from seed limitation because the plots were seeded four times in the first 2 years. Also, there was no lack of volunteer seed coming on to the site as shown by the abundant volunteer vegetation surrounding the plots with rock layers and covering the plots without rocks. The plots with rocks had a nonsignificant trend toward decreasing cover with increasing depth of rocks but the variation in the rock treatment plots was high with 8 of 12 having $3 \%$ cover or less.

The exposed soil at the edges of the plots with rock layers had the most abundant vegetation on the site. This suggests that the temperature and moisture conditions beneath the rocks were amenable to plant growth similar to that observed by Gyasi-Agyei (2004). Based on the plot edge observations and the lack of vegetation in the shallowest rock-mulch depth studied here $(10 \mathrm{~cm})$, the depth of a rock layer that can establish vegetation within 3 years on this site is less than $10 \mathrm{~cm}$. For $10 \mathrm{~cm}$ and deeper rock layers, it may take more than 3 years before vegetation establishes.

A mosaic of rocks and either local soil or growth media similar in texture to local soil (Waugh et al. 1993) may offer a better chance for vegetation establishment and slope stability. While rock layers can be more expensive than other options (Thornton, Abt, and Johnson 1998) and may not support vegetation quickly, as part of an integrated approach, rock can help mitigate the erosion risks of fire, rainfall, and disturbance as sites evolve over time (DeJong, Tibbett, and Fourie 2015).

\section{Funding}

This work was supported by the Rosemont Copper Company [Grant Number 2013 -1] and University of Arizona Agricultural Experiment Station [Grant Number ARZT-1361260-H12-217].

\section{ORCID}

Jeffrey S. Fehmi (D) http://orcid.org/0000-0003-0618-9740 


\section{References}

Blight, G. E., and F. Amponsah-da Costa. 2004. Towards the 1000-year erosion free tailings dam slope - a study in South Africa. In Ground and water bioengineering for erosion control and slope stabilization, ed. D. H. Barker, A. J. Watson, S. Sombatpanit, B. Northcutt, and A. R. Maglinao, 365-77. USA: Science Publishers, Enfiled, New Hampshire.

DeJong, J., M. Tibbett, and A. Fourie. 2015. Geotechnical systems that evolve with ecological processes. Environmental Earth Sciences 73:1067-82. doi:10.1007/s12665-014-3460-x

Gyasi-Agyei, Y. 2004. Optimum use of erosion control blankets and waste ballast (rock) mulch to aid grass establishment on steep slopes. Journal of Hydrologic Engineering 9(2):150-59. doi:10.1061/ (ASCE)1084-0699(2004)9:2(150)

Kaseke, K. F., A. J. Mills, J. Henschel, M. K. Seely, K. Esler, and R. Brown. 2012. The effects of desert pavements (gravel mulch) on soil micro-hydrology. Pure and Applied Geophysics 169:873-80. doi:10.1007/s00024-011-0367-2

Katra, I., H. Lavee, and P. Sarah. 2008. The effect of rock fragment size and position on topsoil moisture on arid and semi-arid hillslopes. Catena 72:49-55. doi:10.1016/j.catena.2007.04.001

Li, X. and L. Lui. 2003. Effect of gravel mulch on Aeolian dust accumulation in the semiarid region of China. Soil \& Tillage Research 70:73-81. doi:10.1016/S0167-1987(02)00137-X

Sheoran, V., A. S. Sheoran, and P. Poonia. 2010. Soil reclamation of abandoned mine land by revegetation: a review. International Journal of Soil, Sediment and Water 3(2), Art 13. http:// scholarworks.umass.edu/intljssw/vol3/iss2/13.

Smets, T., J. Poesen, and E. Bochet. 2008. Impact of plot length on the effectiveness of different soilsurface covers in reducing runoff and soil loss by water. Progress in Physical Geography 32:654-77. doi:10.1177/0309133308101473

Thornton, C. I., S. R. Abt, and T. L. Johnson. 1998. Gully stabilization methods using launching stone. In Water Resources Engineering 98: Proceedings of the International Water Resources Engineering Conference, ed. S. R. Abt, J. Young-Pezeshk, C. C. Watson, 1559-64. American Society of Civil Engineers. Reston, Virginia.

Wang, X., Z. Li, C. Cai, Z. Shi, Q. Xu, Z. Fu, and Z. Guo. 2012. Effects of rock fragment cover on hydrological response and soil loss from Regosols in a semi-humid environment in South-west China. Geomorphology 151-152:234-42. doi:10.1016/j.geomorph.2012.02.008

Waugh, W. J., M. E. Thiede, D. J. Bates, L. L. Cadwell, G. W. Gee, and C. J. Kemp. 1993. Plant cover and water balance in gravel admixtures at an arid waste-burial site. Journal of Environmental Quality 23:676-85. doi:10.2134/jeq1994.00472425002300040009x

Zhang, K., W. Zhang, L. Tan, Z. An, and H. Zhang. 2015. Effects of gravel mulch on Aeolian transport: a field wind tunnel simulation. Journal of Arid Land 7:296-303. doi:10.1007/s40333015-0121-1 